\title{
Students' Writing Rhyme Skill in Elementary School
}

\author{
A Suriani ${ }^{1}$, E Sukma $^{2}$, M Sri Lena ${ }^{3}$, Chandra $^{4}$, Habibi $^{5}$ \\ \{arisuriani@fip.unp.ac.id\} \\ ${ }^{12345}$ Universitas Negeri Padang
}

\begin{abstract}
Writing rhyme learning has not developed students' creativity. Students found difficulty in writing rhyme and they tended to rewrite the rhyme given when they were asked to write their own. This study aimed to find out the effect of problem based learning model and learning motivation on students' writing rhyme skill at grade 5 in the state elementary school 3 in Padang. It was a quasi-experimental research with factorial design $2 \times 2$. Purposive random sampling technique was employed to select the sample. Furthermore, data were analyzed using t-test and two way anova. The results of analysis showed that there was a significant difference on students' learning outcomes between students taught using problem based learning model and conventional approach as well as group of student with high and low motivation. Further, there was no significant interaction between problem based learning model and learning motivation on writing rhyme skill.
\end{abstract}

Keyword : Students, Elementary, Skill.

\section{Introduction}

Writing rhyme skill is one of the writing skills taught in elementary school. Writing rhyme is students' activities deliver their knowledge or experience into written form that indicated with rhyming and content. According to Sudarma (2010) writing rhyme skill in learning is an act not only to write rhyme in a rhyme but also to pay attention to requirements of the rhyme itself. For example, it is consisted of 4 lines, rhymed ab-ab, the first two lines rhyme, and the last two lines are contents, and every line consists of 4 to 6 words or 8 to 12 words, and chose an appropriate theme and diction. It can be concluded that one can write rhyme well if he considers requirements in writing rhyme.

Writing rhyme gives an opportunity to the student to express freely [1]. Writing rhyme can be used as media to train and express students' writing skill. In Writing rhyme learning, teachers should guide students to express their though and feeling into written form that consists of lines and imaginative verse with appropriate diction. Then students should be able to read their rhyme with clear pronunciation and intonation. According to Supriyadi (2006) teachers need to guide and provide students with an example so that they want to write a new rhyme or poem.

Based on the observation and interview in the state elementary school 3 in Padang, it was found some problems both from students and teacher in regards writing rhyme learning. The problems the students were: 1) students regard writhing rhyme is difficult, 2) students face difficulty in finding the idea to write rhyme, 3) students are enable to write rhyme. Students' writing rhyme skill was low it is because the rhyme that they wrote was not rhymed ab-ab. Furthermore, the content that students wrote were not related, as a result readers could not understand it. The problems from the teacher: 1) writing rhyme learning was emphasized to 
the result of the writing not the process of students during writing itself, 2) in the process of writing rhyme learning, students were asked to write rhyme according the material on the student's book, 3) teacher has not used various learning models.

One of solutions for the problems above is that using appropriate learning model i.e. problem based learning model. Problem based learning model is instructional model that challenging students to lean to learn and work together in group to find solution for a problem. Problems in learning used to relate student's curiosity and analysis ability and initiation with learning material. This model prepares students to think critically and analytically and, to find and use appropriate learning sources (Amir, 2009). Problem based learning model has some characteristics: 1) problem used in the beginning of learning, 2) problem challenges student to obtain new learning space, 3) self directed learning, 4) collaborative, communicative and cooperative learning.

Another solution is that pay attention to students' learning motivation because motivation serves as encouragement effort and achievement. Learning motivation is one of the factors that influence learning outcomes (Mappeasse, 2009). High motivation will improve learning outcome, and on the other hand. This research aimed to describe interaction between problem based learning model and motivation on writing rhyme skill at grade 5 student in the state elementary school 3 in Padang.

\section{Method}

This research was quasi experiment to describe causal relationship using experiment and control class (Ibnu dkk, 2003). This research employed factorial design 2x2 it can be seen in table 1. This study was conducted in at grade 5 student in the state elementary school 3 in Padang. Sample of this research was 58 students consisted to 28 students in experiment class and 30 students in control class. Questionnaire of motivation and test were used as instruments. Data were analyzed using t-test and two way anova.

Table 1. Factorial design $2 \times 2$

\begin{tabular}{ccc}
\hline $\begin{array}{c}\text { Learning model/approach } \\
\boldsymbol{\&}\end{array}$ & $\begin{array}{c}\text { Problem Based } \\
\text { Learning Model } \\
\left(\mathbf{B}_{1}\right)\end{array}$ & $\begin{array}{c}\text { Conventional } \\
\text { approach } \\
\left(\mathbf{B}_{2}\right)\end{array}$ \\
\hline Learning motivation & $\mathrm{A}_{1} \mathrm{~B}_{1}$ & $\mathrm{~A}_{1} \mathrm{~B}_{2}$ \\
Low $\left(\mathrm{A}_{1}\right)$ & $\mathrm{A}_{2} \mathrm{~B}_{1}$ & $\mathrm{~A}_{2} \mathrm{~B}_{2}$ \\
\hline
\end{tabular}

Description:
$\mathrm{A}_{1} \quad$ : High learning motivation
$\mathrm{A}_{2} \quad$ : Low learning motivation
$\mathrm{B}_{1} \quad$ : Problem based learning model group
$\mathrm{B}_{2} \quad$ : Conventional approach group
$\mathrm{A}_{1} \mathrm{~B}_{1} \quad$ : Students' writing rhyme skill that had high learning motivation taught using problem based learning model
$\mathrm{A}_{2} \mathrm{~B}_{1} \quad$ : Students' writing rhyme skill that had low learning motivation taught using problem based learning model
$\mathrm{A}_{1} \mathrm{~B}_{2} \quad$ : Students' writing rhyme skill that had high learning motivation taught using conventional approach
$\mathrm{A}_{2} \mathrm{~B}_{2}$ : Students' writing rhyme skill that had low learning motivation taught using 
conventional approach

Motivation in this study was divided into two categories high and low. If student's score < median it was low, and If student's score $\geq$ median, it was high.

\section{Results and Discussion}

The result of students' writing rhyme skill and motivation can be seen in the table 2 bellow.

Table 2. Result of students' writing rhyme skill and motivation

\begin{tabular}{lcccc}
\hline Group & $\begin{array}{c}\text { Learning } \\
\text { Motivation }\end{array}$ & Mean & SD & N \\
\hline Problem Based Learning & Low & 79.09 & 5.56 & 14 \\
Model & High & 82.73 & 8.90 & 14 \\
& Total & 80.91 & 7.51 & 28 \\
Conventional Approach & Low & 72.70 & 7.74 & 15 \\
& High & 76.69 & 9.98 & 15 \\
& Total & 74.70 & 9.01 & 30 \\
\hline
\end{tabular}

Table 2 describes the mean of students' writing rhyme skill using problem based learning model was 80.91. It was higher than using conventional approach i.e. 74.70. Meanwhile, the mean of students' writing rhyme skill using problem based learning model with higher learning motivation was 82.73. It was higher than using conventional approach with high learning motivation i.e. 76.60. Furthermore, the mean of students' writing rhyme skill using problem based learning model with low learning motivation was 79.09. It was higher than using conventional approach with low learning motivation i.e. 72.70. Based on data and t-test and two way anova with $\alpha=0,005$, the following paragraphs describe the discussion of this research.

\subsection{The effect of Problem Based Learning Model on Writing Rhyme Skill}

Based on data analysis, it can be concluded that problem based learning model is better than conventional approach. From t-test it was obtained variant was $8.3, \alpha=0.05 \mathrm{dk} 56 . \mathrm{t}_{\text {hitung }}$ was 2.87 and $t_{\text {tabel }}=2.004$. Thus, $t_{\text {hitung }}>t_{\text {tabel }}, H_{0}$ was rejected and $H_{1}$ was accepted meaning students' writing rhyme skill taught using problem based learning model was better than those taught using conventional approach. This result was supported by previous research conducted by Moestofa dan Soindang (2013) and Abdussamad et.all (2013) stated that students' learning outcomes using problem based learning model was better than those taught using conventional

\subsection{The effect of Learning Motivation on Writing Rhyme Skill}

The result of t-test it was obtained variant was $9.48, \alpha=0.05 \mathrm{dk} 27$. thitung was 1.7217 and $t_{\text {tabel }}=1.703$. Thus, $t_{\text {hitung }}>t_{\text {tabel, }}, H_{0}$ was rejected and $H_{1}$ was accepted meaning students' writing rhyme skill with high learning motivation taught using problem based learning model was better than those with high learning motivation taught using conventional approach.

On the other hand, the result of t-test it was obtained variant was $6.78, \alpha=0.05 \mathrm{dk} 27$. $t_{\text {hitung }}$ was 2.546 and $t_{\text {tabel }}=1.703$. Hence, $t_{\text {hitung }}>t_{\text {tabel}}, H_{0}$ was rejected and $H_{1}$ was accepted meaning students' writing rhyme skill with low learning motivation taught using problem based learning model was better than those with low learning motivation taught using conventional approach. 


\subsection{Interaction of Problem Based Learning Model dan Learning Motivation with Writing Rhyme Skill}

The result of F-test showed $F_{\text {count }}$ was 0.007 , while $F_{\text {table }}$ was 4.022. Therefore, $F_{\text {count }}$ was lower than $\mathrm{F}_{\text {table, }} \mathrm{H}_{0}$ was accepted and $\mathrm{H}_{1}$ was rejected meaning there was no significant interaction between problem based learning model and students learning motivation on writing rhyme skill. It could be seen from the students' average result of writing rhyme through problem based learning model and conventional approach. Meanwhile, using problem based learning model and conventional approach, the students' average result of writing rhyme with high learning motivation tended to be higher than with low learning motivation. It can be seen on line graph 1 bellow.

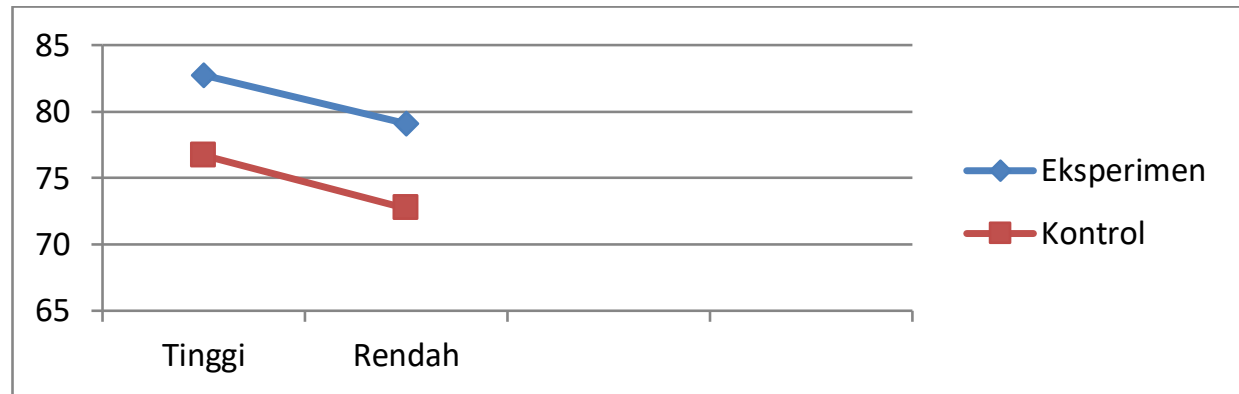

Fig.1. Result of writing rhyme with high learning motivation tended to be higher than with low learning motivation

The line graph above indicates that learning model and students' learning motivation had no interaction. Budiyono (2009) explained that the interaction can be seen from the graph of profile of the independent variables. The line graph above shows the students' average result of writing rhyme taught using problem based learning model were higher than taught using conventional approach. Students with higher learning motivation were better than low learning motivation using problem based learning model and conventional approach.

Learning motivation and learning model had discretely effect on learning outcome. Learning motivation encourage students to learn better, while learning model is a pattern used in setting, creating, delivering learning material, organizing student to accomplish learning objective and optimal concept understanding that conducted by the teacher. This results in line with research conducted by Amin (2012), showed that learning activity using media satket and media interactive, students' engagement was the same, both those with high and low motivation.

\section{Conclucion}

Based on data analysis and discussion, it can be concluded that problem based learning model influenced students' writing rhyme skill. First, students' writing rhyme skill taught using problem based learning model were better than students taught using conventional approach. Second, students' writing rhyme skill that had high learning motivation taught using problem based learning model were better than students that had high learning motivation 
taught using conventional approach. Third, students' writing rhyme skill that had low learning motivation taught using problem based learning model were better than students that had low learning motivation taught using conventional approach. Fourth, there was no significant interaction between problem based learning model and students' motivation on students' writing rhyme skill.

\section{References}

[1] Abdussamad dan Ramdani. (2013). "Peningkatan Memahami Perintah Kerja Tertulis dengan Problem Based Learning Siswa SMK Negeri3 Pontianak". Jurnal Pendidikan dan $\begin{array}{lllll}\text { Pembelajaran. } & \text { Volume } & 2 & \text { No } & 1 .\end{array}$ (http://jurnal.untan.ac.id/index.php/jpdpb/artikel/view/857, diakses 10 November 2016).

[2] Amin, S., Widha Sunarno, dan Suparmi. (2012). "Pembelajaran Fisika dengan Media Satket dan Media Interaktif Ditinjau dari Motivasi Belajar dan Motivasi Belajar Siswa”. Jurnal Inkuiri Pascasarjana UNS, 1 (1), 69-77.

[3] Budiyono. (2009). Statistika Dasar untuk Penelitian. Surakarta: Universitas Sebelas Maret.

[4] Mappeasse, M. Y. (2009). Pengaruh Cara dan Motivasi Belajar terhadap Hasil Belajar Programmable Logic Controller (PLC) Siswa Kelas III Jurusan listrik SMK Negeri 5 Makasar. Jurnal Medtek, Vol 1 No. 2. (Online), (http://jurnal.untan.ac.id/index.php/ipdpb/artikel/view/857, diakses 10 November 2016).

[5] Moestofa, M., \& Sondang S., M. (2013). Penerapan Model Pembelajaran Berbasis Masalah pada Standar Kompetensi Memperbaiki Radio Penerima di SMK Negeri 3 Surabaya. Jurnal Pendidikan Teknik Elektro, 2(1):255-261.

[6] Sudarma, dkk. (2010). Bahasa dan Sastra Idonesia. Bogor: Yudhistira.

[7] Supriyadi. (2006). Pembelajaran Sastra yang Apresiatif dan Integratif di Sekolah Dasar. Jakarta: Depdiknas Direktorat Dirjen Dikti.

[8] D. Coleman and D. S. Willis, "Reflective writing: the student nurse's perspective on reflective writing and poetry writing," Nurse education today, vol. 35, no. 7, pp. 906-911, 2015. 